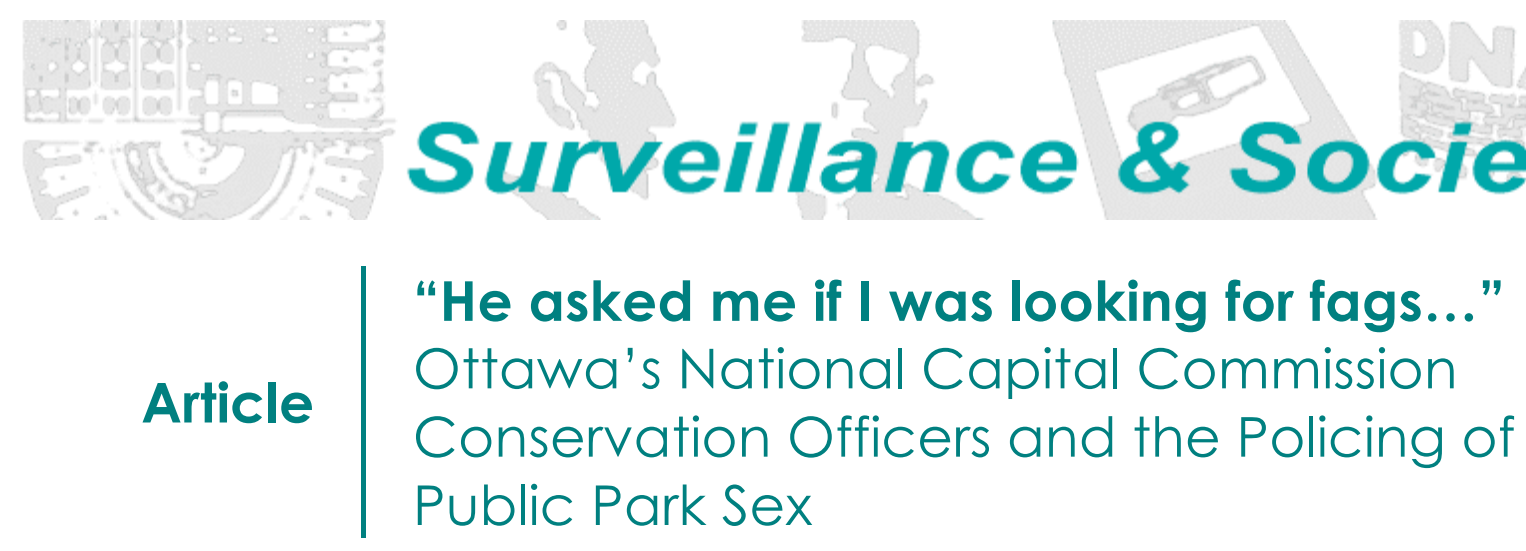

\title{
Kevin Walby
}

Department of Sociology and Anthropology, Carleton University, Canada. kwalby@,connect.carleton.ca

\begin{abstract}
The National Capital Commission (NCC) is an organization responsible for so-called 'beautification' and land development around Canada's capital city, Ottawa. This paper examines surveillance of public sex by NCC conservation officers in Ottawa's parks. Conceptualizing NCC conservation officer work as policing, I analyze conservation officer occurrence reports obtained through federal-level access to information requests to examine how public male with male sexual activity is problematized and criminalized. This case study of NCC conservation officer work demonstrates how notions of so-called 'appropriate' sexuality and space usage can be shaped and reinforced through policing and surveillance conducted by governance agents who have peace officer status. Conservation officers have been excluded from studies of policing because of a bias towards conventional municipal officers in the policing literature as well as the marginal status of specialized enforcement agents. Contributing to the literature on policing of public sex, my analysis of conservation officer occurrence reports suggests that even when bylaws and park regulations concerning erotic acts are written in gender-neutral and innocuous language, these bylaws are enforced in ways that discriminate against public homoeroticism. Though NCC officer policing is integral to attempts at purifying urban space, because of their mandate to promote the spirit of Canada in the lands surrounding Ottawa I argue that sexuality is also a matter of national character for the NCC.
\end{abstract}

\section{Introduction}

The literature regarding male with male public sex tends to focus on bathhouses (Bérubé 1996; Alexander 1996; Smith 1988) and tearooms (Walby 2009; Johnson 2007; Deroches 1990; Delph 1978; Humphreys 1975). Whereas bathhouses charge men money for lockers and rooms to conduct sexual acts, tearooms are public settings for encounters where participants are less often known to each other. Public parks are also spaces where men seek sexual relations with other men. Parks are dark at night, and are less 'public' than street corners, so men who frequent these "erotic oases" (Delph 1978) hope they are not disturbing anyone and also hope they are not being monitored by police.

Compared with tearooms, parks are interesting as erotic oases because they are not used exclusively by men having sex with men (Tewksbury 1996). Heterosexual couples also head to the park. All of this erotic activity in parks transgresses the contemporary spatial bounds of sex, which limits it to the private realm, the home, the bedroom. Park sex is contested (Rubin 1993) since it contravenes assumptions about where sex should happen and how parks should be used. Parks known as cruising zones for public sex are frequently regulated, through techniques ranging from tree removal and landscaping to arrests. Landscaping or 'beautification' that targets park sex amounts to a 'crime prevention through environmental design' mentality of policing eroticism. 
Tewksbury (1995: 9) writes that "truly open locales such as public parks have been largely neglected in the literature" concerning policing of sex. Meanwhile, Carter (2006) notes that game wardens as well as conservation officers have been excluded from studies of policing because of a bias towards conventional municipal officers in the policing literature as well as the marginal status of specialized enforcement agents. In this paper I examine the surveillance and policing practices of National Capital Commission (NCC) conservation officers with respect to sexual relations in the public parks of Canada's capital city, Ottawa. I argue that National Capital Commission conservation officer surveillance work is policing. The $\mathrm{NCC}$ is an organization responsible for land development projects and so-called 'beautification' around the National Capital region, which extends outside of the City of Ottawa into surrounding townships. NCC conservation officers monitor the parks under their jurisdiction, write up occurrence reports, correspond with the Ottawa Police as well as the Royal Canadian Mounted Police about their findings, and enforce NCC regulations as well as the Criminal Code of Canada.

Urban governance agencies like police and security firms have tenuous relationships with queer communities. Through their surveillance and occurrence reporting practices that attempt to ban sex (especially male with male sex) from public, NCC conservation officers are involved in the normalization of sexuality. Situated on the Ontario/Quebec border, Ottawa is distinct as a capital city but also because of its specific cultures of gay masculinity. Ottawa is more 'in the closet' than the neighbour cities of Montreal and Toronto (located 2 and 5 hours by car away respectively). Community associations from both Ontario and Quebec problematize sexual activities in parks, which only strengthens the NCC mandate to enforce regulation \# 18 of the National Capital Commission Traffic and Property Regulations, which states: "no person shall use any blasphemous or indecent language, or behave in an offensive manner, upon any property of the Commission". NCC conservation officers have a specific mandate to enforce this regulation on their lands. The chief method by which NCC officers find out if sexual relations are occurring is to cruise around the parks by car, bike or foot, though they sometimes check online chat sites to monitor communications about where people are likely to congregate. NCC officer policing is integral to attempts at "purifying space and the concomitant eradication of strangeness" that Bell and Binnie (2004: 1813) argue is a chief strategy of urban governance today.

When it comes to urban governance, 'beautification,' read another way, is codeword for annulment of sexuality. Yet policing of public sex is not only an urban governance issue. Pryke (1998) argues that attempts to regulate sexual conduct figure centrally in defining who is fully accepted as part of the nation. Charged with a mandate of fostering the spirit of Canada in the lands surrounding Ottawa, sexuality is a matter of national character for the NCC, which, in this case, leads to the barring of male homoeroticism from public. Through their policing, NCC officers are not only defining what sexual identities and practices are acceptable in certain city spaces. NCC officers are also at work producing a vision of sexual citizenship (Hubbard 2001), since, as a National Capital Commission (1965) document puts it, "the capital of a country...becomes a symbol of nationalism and in miniature represents the spirit and life of its people".

This paper is organized in four parts. I first review the literature regarding public sex as it concerns anonymous zones for male with male public sexual relations. I then offer an overview of the National Capital Commission as an organization and the work of NCC conservation officers as police. After a note regarding research method, I report on the findings from federal-level access to information requests I filed with the NCC as it concerns public male with male sex. The activities of sex participants are inscribed as spatially and sexually deviant through NCC officer use of occurrence reports. My analysis of conservation officer occurrence reports suggests that even when regulations concerning sexuality are written in gender-neutral and innocuous language, these are enforced in ways that discriminate against public male with male sexual relations. Contributing to the literature on policing of public sex, I argue that not only is NCC officer policing integral to attempts at purifying and heterosexualizing urban space, but is integral to fostering a heteronormative understanding of nationhood in and around Canada's capital city. 


\section{Public Sex, Parks and Surveillance}

The notion of 'public sex' is misleading. It assumes there is a stable difference between 'public' and 'private'. Edwards (1994: 91) uses the term 'not-private' sex, since the paradox of public sex is its hiding "in darkness, and around corners to evade constantly increased state surveillance...[oscillating] from apparent non-privacy into comparative privacy". For this reason, so-called public sex involves redefining privacy and anonymity (Bell 1995). Notions of 'public' and 'private' are also central in the regulation of sexuality (Colter et al. 1996). The 1957 Wolfenden Report, influential across the UK and North America, called for complete withdrawal of regulation of sex in the private sphere but broader policing of public sex. The Wolfenden Report became core policy for many governments, including Canada's, facilitating the decriminalization of private 'homosexuality' in a 1969 amendment of the Criminal Code of Canada. The Wolfenden Report simultaneously legitimated regulation of male with male sex in public, evidenced by crackdowns on bathhouses and tearooms that occurred in Toronto during the late 1970s through the 1980s (Walby 2009; Smith 1988). Decriminalization of 'private homosexuality' was advanced while 'public homosexuality' became criminalized.

As Califia (1994: 71) puts it, too narrow a definition of 'public' or 'private' in relation to sex "could leave us with little or no right to be visibly gay, meet each other in public places, or participate in sex outside of monogamous, closeted relationships". That we are 'free' to pursue sexuality in 'private' means that sex is subject to various forms of regulation. The surveillance that occurs where space and pleasure-seeking intersect is only intensified in the revanchist city (Hannigan 1998; Smith 1996) where business and moral entrepreneurs seek to sanitize space and create more commercial zones.

Laws concerning public sex are written or enforced in ways that target specific types of people in specific locations (e.g. men who have sex with men in public). What results from governing public sex through law "is the performative inscription of a particular type of sexual figure who is deviant, abnormal, suspect, and in need of regulation by the criminal law" (Johnson 2007: 532). The claim here is that not all public sex is regulated equally. If laws are enforced in ways that discriminate against public male with male sexual relations, this begs the questions of why. Is it simply homophobia?

For Herek (2004: 8), the term 'homophobia' was important in that it "crystallized the experiences of rejection, hostility, and invisibility that homosexual men and women in mid- $20^{\text {th }}$ century North America had experienced throughout their lives". But Herek points out that the term 'homophobia' has been "too diffuse in its application" and "overly narrow in its characterization of oppression as ultimately the product of individual fear" (ibid. 11). The stereotyping, persecution and exclusion of men who have sex with men is based on more than an amorphous fear - regulation of sexuality always has a spatial element. Some argue that 'heteronormativity' is a more precise term. Heteronormativity refers to how heterosexuality is privileged as 'natural' sexuality, favouring monogamous relations between opposite sexes that aim towards child bearing. Same sex relations, promiscuity, and kinky sex are shunned. It is not only sex acts but also urban areas that are coded through heteronormative hierarchies of property and propriety (Berlant and Warner 1998). Heteronormativity is not a thing, however, it is a process. The privileging of heterosexuality and demonization of queer sexuality is achieved and inscribed through routine text-based surveillance practices (Smith 1988) involving occurrence reports and other kinds of information sharing. Governance of homoerotic desire occurs in a field of contending discourses, where multiple techniques are used to produce regulatory knowledge in a search for 'homosexuals' (Walby 2009; Kinsman 1996).

The heteronormative order is also a spatial order. Moral contours of heterosexuality are etched into city spaces: "the city organizes and 'naturalizes' heterosexuality in so much as it divides and confines sexual identities across public and private spaces, defining the locations appropriate for specific sexual performances" (Hubbard 2000: 211). Parks are a site of such attempts at ordering. Edwards (1994) writes that parks in Britain have been used for public sex since $18^{\text {th }}$ century industrialization. Merrick (2002) discusses the policing of male with male sex in the then wooded and marshy Champs-Elysées area of $18^{\text {th }}$ 
century Paris. Men having sex with men choose the park because it is more discreet than the street corner. Parks can be public-private spaces. The park is sometimes viewed as risky by sex participants, not because of HIV/AIDS, but since gay bashing from police or homophobic community members is a possibility. This in turn contributes to how men also think of park sex as thrilling and exciting (Lee 1979). For Edwards (1994: 108), "public sex is primarily conducted within the context or parameters of pleasure and danger or eroticism and oppression due to its constant oscillation across a series of codes of decency, order and privacy". The park is a liminal zone where the rules for everyday sexual conduct are suspended. At the same time, the park (especially at night) is thought of as a site where male against female violence occurs (Little 2005; Chan and Rigakos 2002; Pain 1997). Public parks are contested zones because they are accessible by numerous social groups who make different use values of the locale.

Even Christopher Park in New York, iconic in gay communities, is neither stably queer or heteronormative (Conlon 2004). Instead, it is through contestation that space becomes produced or intelligible as belonging to one or another social group and the conduct associated with them. It is not only 'private' and 'public' that are constituted through such regulation and surveillance. It is through surveillance that 'homosexuals' as so-called sexual deviants become intelligible as governance objects to organizations like the NCC. Examining the textual organization of surveillance practices and the work of surveillance agents (Walby 2005), in this paper I focus on how the NCC as a governance agency mobilizes against and monitors people with diverse sexualities.

\section{Conservation Officers and the National Capital Commission}

The $\mathrm{NCC}^{1}$ is unique as a governance agency because its purpose is ostensibly 'beautification' of public space around Ottawa, yet it touts a specialized team of conservation officers with powers to enforce NCC regulations and the Criminal Code of Canada. Capital cities often have planning commissions. Part of the commission's task is to manage the city's image. Even though Ottawa was selected as Canada's capital in 1857, its reputation as a debauchery-ridden town did not catch up with it until Canada's second Prime Minister, Sir Wilfred Laurier, sought in the late 1890 s to halt private development initiatives linked to alcohol consumption and prostitution along the river bank, making all land development a matter of public interest (Besmier 2003). A gang of landscape architects took to beautifying Ottawa, trying to make its lands and buildings reflect the diversity of Canada. In 1899 lands were bestowed to the Ottawa Improvement Commission, which was then replaced in 1927 by a more ambitious organization, the Federal District Commission. In 1956, the federally funded National Capital Commission took over from the Federal District Commission, with powers to ensure development of the newly created National Capital Region. The NCC's mandate changed under the Conservative government of Brian Mulroney. In addition to the NCC being responsible for development projects along the Rideau Canal and Rideau River, it now had a specific mandate to build pan-Canadian national identity (Besmier 2003). Ottawa's buildings and public space had to take on a symbolic thrust and create an imaginary of Canadian nationalism.

There are two ways the NCC aims to police public sex, first through beautification and second through conservation officer surveillance. The 'beautification' engaged in by the NCC, which involves landscaping and tree removal to deter park sex, can be conceptualized as crime prevention through environmental design (CPTED). CPTED involves using design to encourage proprietary behaviour among users of the space. Removal of trees and increasing lines of sight augments casual surveillance of so-called anti-social behavior by other space users. The space is created in an image of respectability - nuclear family values are part of the planning and design (Parnaby 2007). CPTED is about risk management, not just crime prevention. This requires some device for sorting people into categories of those who appropriately use space and those who do not (Parnaby 2006). When it comes to parks, CPTED is

\footnotetext{
1 The NCC is a crown corporation under the jurisdiction of the Canadian Heritage Department. Its board is comprised of members from the City of Ottawa, members of other municipalities and representatives from the provinces of Ontario and Quebec. The NCC has no control over the City of Ottawa but works in 'partnerships' with them, local authorities, as well as land and building development companies. In addition to conservation officers, the NCC employs engineers, architects, regional planners and surveyors.
} 
gardening aimed at governing: "through physical design, this sense of proprietary concern can be extended into public space” (Blomley 2004: 617).

If so-called beautification fails to deter use of the park for sex, NCC conservation officers step in. NCC conservation officers have peace officer status. Their powers include serving of summons and warrants, arrest, search and seizure, the option of carrying protective devices such as pepper spray and batons, and access to the Canadian Police Information Centre (CPIC) database. CPIC is a database run by the Royal Canadian Mounted Police that all police and peace officers can consult for background information (e.g. previous offenses) of people they have apprehended. Though CPIC files are not supposed to contain 'soft' background information like details of past warnings in the form of 'cautions' officers leave for each other, CPIC files do contain this information, and sometimes this information is used in a prejudicial way against those apprehended (Schellenberg 1997). Peace officers are thus "contiguous" with law enforcement officers (Bittner 1967: 714) since they have access to many of the same tools and use law as a resource to tackle problematized groups.

The ability of NCC officers to enforce law and use CPIC is justification for conceiving of their work as policing. Carter (2006) argues that game wardens as well as conservation officers have not been conceptualized as police, though they should be. Hermer (2002) has examined the role of game wardens and rangers in regulating parks, but most of the parks he looked at were state or provincial parks removed from urban settings. NCC parks are in or very near the city. This means NCC officers are presented with a different set of duties compared to conservation officers who work in remote locations. The NCC parks in and around Ottawa are close enough that they can be accessed by those interested in a cruise. 'Cruising,' or picking up a date in public for a casual sex encounter, occurs in semi-urban environments that offer anonymity. Communication for this pick-up system happens through bodily signals and coloured handkerchiefs (e.g. dark blue for fucking, light blue for sucking). NCC conservation officers have to blend in and not blow their cover, which is facilitated by plain clothes patrols.

One policing tool that conservation officers have at their disposal when they apprehend people having park sex is the occurrence report. Occurrence reports are notes made by NCC conservation officers about their surveillance work. The report has sections for the name of the officer, the location of the occurrence, details of the occurrence, the number of the infraction or warning given, CPIC codes, officer signature, and date. Occurrence reports like those the NCC conservation officers work with are key tools in the material relations of surveillance because they allow for monitored activity to be translated into written language, which can then be stored, sent to other governance agencies, and used to prohibit from certain spaces and sometimes criminalize those about whom the report was written (Walby 2006). Through access to information requests I received seventy five occurrence reports filed by NCC conservation officers between 2004-2007. This is just a small sample of all the occurrence reports regarding public sex filled out over time. My concern is not the quantity of these occurrence reports but what NCC conservation officers do with them in monitoring and regulating sex in Ottawa parks. I argue that NCC police work is not only a matter of urban governance but also relates to the NCC mandate of pursuing an idealized conception of Canadian nationhood.

\section{Note on Method}

In Canada, the Access to Information Act allows individuals to request information from public organizations that would not otherwise be made public. I requested reports, internal/external communications and/or briefing materials prepared by National Capital Commission regarding public sex, public sex in NCC parks, and policing of, or concerns regarding, public sex. I received back seventy five occurrence reports from between 2004-2007 as well as many other documents related to policing of public sex. Some of the documents had information redacted using section 19(1) of the Act, which pertains to personal information. I also accessed numerous reports and public complaints through the request. To supplement the analysis of occurrence reports, I have also analyzed stories concerning public sex in the Ottawa Citizen newspaper. 


\section{Keeping Track of 'Criminal Intimacies' in NCC Parks}

Before analyzing NCC conservation officer regulation and surveillance of park sex, I will provide background information concerning how public sex has recently been problematized by community groups and police in Ottawa. In the late 1980s, residents in the Tunney's Pasture area of Ottawa complained about men using the Remic Rapids Park for sexual encounters. One concerned mother feared her son would contract a disease from used condoms or be molested by gay men (Ip, June 15 1987: C20). Using CPTED strategy, the NCC tried to change the landscape of the Remic Rapids Park, which had been a cruising zone since the 1940s, by adding lights as well as removing all trees higher than five feet and bluffs that concealed sexual activity. Gay-ally groups responded that cruising locations had been diminished because the new National Gallery of Canada, constructed in 1987-1988, attracted crowds that made sex at Nepean Point Park untenable. The Alderman of Elmdale said "fornication in the bush" is "unacceptable behavior," while the NCC contacted the Royal Canadian Mounted Police to increase patrols in the Remic Rapids area. A spokesperson for the Gays of Ottawa group said that parks were needed as cruising zones since homoeroticism was denigrated in society (Oslund, June 22 1989: B1). A resident responded "I have nothing against consenting adults getting intimate...but I just wish they would find some place more private". As Hubbard (2001: 51) puts it, "public spaces are constructed around particular notions of appropriate sexual comportment which exclude those whose lives do not centre on monogamous, heterosexual, procreative sex".

A liaison committee was formed in 1991 to advise police on queer issues. Also in 1991, as a way of dealing with complaints about park sex while accommodating (mostly) gay men's frequenting of parks for sex, a 'pink granite road' was proposed as a cruising site. In conjunction with Planned Parenthood Ottawa, the NCC proposed to spend $\$ 10,000$ on condom machines in washrooms on NCC grounds and condom distribution in parks. Representing public sentiment concerning the condom program, one reader of the Ottawa Citizen wrote "this is a totally unacceptable use of Canadian tax dollars. Our national capital greenbelt areas are funded for family use and recreation, not copulation" (Smith, April 15 1991: A10). When the NCC removed all shrubbery along the City's Western Parkway, citing that motorists could not see the Ottawa River during sunset, the AIDS Committee of Ottawa accused the NCC of cracking down on cruising zones.

There is a dynamic of development and displacement behind how zones constituted as erotic oases become located by sex participants but also regulated by governance agents like NCC officers. When in 1998 the American embassy was being erected in downtown Ottawa, the Major's Hill Park male with male scene again headed to Remic Rapids Park. In 2000, the Remic Rapids area was problematized by some residents who believed "we've really lost that region" (Manchulenko, March 25 2000: C3). Another resident said "this is not a community saying No to the gay community...this is a community saying No to any kind of this activity". 'Appropriate' use of parks is framed as exclusive of sexuality.

Of the seventy five occurrence reports from 2004-2007 that detail NCC conservation officer surveillance work, five of the occurrence reports had to do with sexual assaults by men against women or so-called 'path perverts' like flashers who exposed themselves to women on park paths. The other seventy occurrence reports had to do with NCC conservation officer correspondence, observations and interventions regarding public sex. There were interventions (the issuing of a ticket or fine, or expulsion from the park) in forty four of the seventy cases concerning public sex. Of the twenty six other occurrence reports not regarding interventions, several were generated in response to public complaints, Ottawa Police or Royal Canadian Mounted Police correspondence, newspaper articles or information attained on the Internet about popular cruising locations. Many of the public complaints had to do with used condoms.

The typical occurrence report has information such as the following written on it: "TOPIC- behavior in an offensive manner. DETAILS- while on foot patrol with another NCC officer observed two males having oral sex in the brush. ACTION TAKEN- Intercepted. ID ourselves, advised of the NCCTPR regulations, 
issued 2 tickets \#18". In another occurrence report it was written: "DETAILS- observed one male mast[u]rbating in front of 2 other men. ACTION TAKEN- Tried to intercept, ran off. Intercepted shortly thereafter. Advised of the NCCTPR regs, issued ticket \#18". Or, the more shamefaced: "DETAILSobserved two suspects behaving in an offensive manner (having s--)". We may laugh, but as Foucault (2003) put it in his introduction to Parallel Lives, these descriptions and transcriptions are products of excessive police vigilance, inscribing secret passions as problematic. Homoeroticism becomes "describable and transcribable" (pg. 289) as police help "the quotidian to enter into discourse" (pg. 293). The language of regulation \#18, that "no person shall use any blasphemous or indecent language, or behave in an offensive manner, upon any property of the Commission," is written in a gender-neutral and innocuous language, but, as I demonstrate below, the regulation is not enforced equally against all sexualities.

Policing activity is comprised of monotonous paper work and report writing. Police occurrence reports are often devoid of detail. Sometimes the occurrence reports are more like communiqués between conservation officers, as in the following where one officer wrote "FYI primetime is around 12:00...Timm Road seems to be their new favorite spot to have fun". Or in another report: "highly advertised on website... supposedly to be highly active today!!! CO's heads up!" Monitoring sexual activity in NCC parks is only one of the duties of a conservation officer. NCC officers monitor internetbased gay chat rooms to pick up information concerning cruising sites. NCC officers routinely distribute 'illegal parking' tickets to cars parked in NCC lots past eleven o'clock in the evening.

Actual monitoring of sex in parks is the officer's most voyeuristic duty, however. In one report from 2007-07-31 it was written:

Encountered one caucasian male, 6'2", slim build....he asked me if I was looking for fags...I asked him if he wanted to file a complaint...he answered 'no, I am gay'...he advised me that I was always welcome to walk this area?? I asked him his name, he asked mine and we shook hands...

There are two ways of reading this encounter. First, as Tewksbury (1995) points out, in the USA it is common for plain clothes police to solicit men in parks for sex to entrap them under the criminal laws concerning prostitution. This conservation officer, if trying to entrap the man, certainly blew his cover. Since the park is a known cruising area and the officer is in plain clothes to avoid detection, this encounter itself verges on 'entrapment' or what in Canadian law is referred to as random virtue testing. The logic of law mimics this logic of the lure (Ricco 2002), negating pleasure in the making. Another way of reading the encounter is to understand the gay man as recognizing the officer, confronting him, claiming the park as cruising space. Chauncey (1994) discusses the undulation of gay men claiming parks as theirs, and police responding with an aim to control use of public space.

Just like men must blend in if they want to find a temporary mate, NCC officers must blend in if they want to intercept someone and issue a ticket. Having sex in public is complicated because of sight lines. Yet visibility also makes it difficult to be the voyeur. Voyeurism has traditionally been linked with the peeping tom (Marx 2002) and Califia (1994: 81) has written about the voyeuristic pathology of policing public sex: "I wish all the cops hiding in the bushes and sneaking around public restrooms would get out there and prevent more serious crimes like littering and dogs pooping on sidewalks". Officers whose jobs compel them towards voyeurism are not watching over with care - they are out to enforce regulations. In one occurrence report, the officer is just waiting for the blowjobs to begin so he can lay a charge: "while on foot patrol observed several groups in the bush. Could not get a clear view of illegal activity, except for one... intercepted person with his pants down. Issued written warning (not enough for a charge)".

An ideal voyeur goes largely undetected. If the NCC conservation officer becomes more than a voyeur, and becomes known as a peace officer, their shift in the park is over. Blending in is no easy task when the vehicles they drive tout NCC decals. Cruisers have developed methods for alerting others that an officer is 
in the park. In one NCC occurrence report it was written " 5 cars in the lot. Man with a dog blew a whistle to blow our cover. All cars left fast". The next day, while pensively hiding behind a tree and monitoring the parking lot, "we were once again observed by the same individual. He blew his whistle". Another time, "I started by foot patrol, an individual in his pick-up truck started his vehicle alarm alarming all the others. I went to see him, and said what was that was for? He said his dog has sat on his keys (with a great big smile on his face)...my patrol was over even before it started". Just like Humphreys' (1975) watchqueen who kept an eye out for police and passers-by, those who blow the cover of NCC conservation officers create their own rules and play a role in contesting NCC regulation of park sex. Men having sex with men in parks enjoy anonymity, and take measures to protect the space as anonymous despite the persistence of NCC officers. Sometimes, however, the NCC officers use unmarked cars or bicycles.

Those interested in public sex do not always go to the same parks. There is internet communication for finding out where to be and when, which NCC conservation officers also monitor. The access to information request results I received did include a number of communications that NCC officers had intercepted about public sex locations in Ottawa parks and the surrounding greenbelt. Activity in certain affluent areas, like Rockcliffe Park for instance, becomes a concern for conservation officers so they will write comments such as "we have a serious problem here!!!" In "the same area where there were some boy scouts yesterday," one officer noted of Rockcliffe Park in 2006, "the problem may continue to escalate if no immediate action taken". Action includes alerting Ottawa Police Service (OPS) and Royal Canadian Mounted Police (RCMP) of sex 'hotspots' and coordinating blitzes of these locations. After a complaint from an NCC trail user about a "disgusting mess" of condom wrappers, NCC officers corresponded about how to counter. The lead conservation officer asks a group of others through email if they are able to do "a little enforcement" and anything "aside from doing more intensive brush clearing". The NCC and OPS coordinate to have persons who are repeatedly apprehended banned from NCC lands. Like municipal police, the NCC steps up patrols after community complaints. Enforcement teams frequent the parks so much that one man who enjoyed canoeing on NCC waterways complained in a letter that "as soon as I visit a park or lookout by myself, I instantly become a suspect by the police who patrol these areas".

\section{Some Consequences of NCC Conservation Officer Surveillance and Enforcement}

NCC conservation officer surveillance of sex in parks is not an inconsequential game of cat and mouse played between officers and those cruising. This is not only reassurance policing to appease concerned community members -- the fines and charges are real penalties. Men caught having sex with men are usually 'outed' to family and/or co-workers. Ostracism from familial, religious or other circles is all too common. The following occurrence report demonstrates what the consequences of being caught can be:

While patrolling the Ottawa River near Bates Island I observed 3 males performing oral sex. The minute they saw me they all ran away. Intercepted two individuals 10 minutes later. One left in his vehicle. I got the plate. It almost caused an accident. Called the RCMP for assistance and they arrived...one male gave a fake ID...I issued tickets on site... Constable St-Amour from the RCMP and myself went to the address to serve the client. Arrived there and spoke with the wife and explained the situation. Gave the ticket to the wife and she saw a picture to confirm ID.

The NCC conservation officer would have been able to locate the address of the fleeing man by looking up his license plate in CPIC. Enforcement of NCC regulations problematize secret passions between men, an example of what Ericson (1981) long ago referred to as the police process of "making crime". The next case is likewise one of NCC officers and police criminalizing male with male sexuality:

While on foot encountered two male subjects engaged in sexual activities...one of them took off running east after officer Horvath recorded his name. The other one was 
cooperative....Later, the first subject was seen walking on Burnside road. We approached in our patrol vehicle. The subject took off again behind properties north of Burnside west of Parkdale. He crossed the Baseball field in Laroche park and was intercepted...OPS was called for backup...the subject was placed under arrest and brought to OPS station where criminal charges were laid for mischief...

For Johnson (2007: 536), "the law, and its application, captures and renders visible activities which would otherwise remain known only to those consenting to engage in them". Laws enable and legitimize the surveillance of park sex carried out by conservation officers. In a different occurrence report, the conservation officer comments on how he encouraged a land developer to get the license plate number of any car entering a park when he believed the man driving it could be 'gay'. Such actions by the NCC officers results in an assumption that all men in the park are cruising, and that cruising is 'inappropriate' as a practice of sexuality. Recognizable differences between private, public, municipal and corporate property break down, or rather, fuse in a way that turns the park into a space policed by discretion and suspicion.

When NCC conservation officers are busy with other duties they refer complaints to the OPS and the RCMP. In 1998 the OPS drafted their 'Strategy for Police Response to Public Sex in Parks,' which includes use of verbal warning and criminal charges. The OPS 'Strategy' document argues public sex between men should be "a low priority for traditional law enforcement intervention such as criminal charges, stings or surveillance geared toward elimination of sexual activity between men". Yet two years after this document was drafted, OPS Sgt. Cameron said the most prevalent complaint always pertains to men having sex with men, so "we want to start before we get the complaints this year" (Manchulenko, March 25 2000: C3). Usually municipal police base their patrols in particular urban areas on frequency of complaints from the surrounding community. In this instance, however, municipal police preemptively try to ban men having sex with men from public space. This is a form of policing that not only responds to crime but also preemptively seeks out and terminates any form of conduct discredited as risky or antisocial (Zedner 2007). Precautionary policing of parks assumes what 'appropriate' use of park space is and attempts to disrupt and displace any other activities. ${ }^{2}$

As stated earlier, the sample of occurrence reports I viewed is only a sliver of what the NCC has compiled since the 1970s. When I analyzed the occurrence reports quantitatively for differences between heterosexual couples versus single men and groups of men with other men, a trend emerged. Of the twenty seven occurrence reports concerning single men and groups of men with other men, twenty four $(89 \%)$ resulted in a ticket or fine of some kind, while only three cases resulted in the man/men being expelled without ticket or fine. Of the seventeen occurrence reports concerning heterosexual couples, only four $(23 \%)$ resulted in a ticket or fine of some kind, while thirteen cases resulted in the couple being expelled without ticket or fine. The tendency of these data substantiate claims by Johnson (2007) and Califia (1994) that even when laws and regulations are written in gender-neutral and innocuous language these are enforced in a biased way against men seeking sex with men.

Occurrence reports are used to inscribe the activities of sex participants as spatially and sexually deviant. Men who seek anonymous sex with other men in concealed areas of Ottawa parks have everything to lose when outed by NCC conservation officers. Through such surveillance and inscription using the occurrence report, the conservation officer constructs men having sex with men as participating in abhorrent sexuality.

\footnotetext{
2 If OPS have shifted to low level policing of public sex, as they claim, this paper suggests the NCC became more enforcement and surveillance oriented in the last decade. In addition to this co-presence surveillance of public sex by NCC conservation officers, the City of Ottawa installed one surveillance camera with night vision at the Remic Rapids parking lot location in 2006.
} 


\section{The Issue of Anonymity}

The case of NCC park sex policing raises a number of questions about anonymity. Men who have sex with men and heterosexual couples use the parks to cruise or have sex because they assume parks on the fringes of town are anonymous zones where personal information about them and their activities will not be collected. Men usually cruise at night so as not to be disruptive and also because there is less chance of being arrested. When ticketed, NCC conservation officers are collecting personal information about those caught breaking the NCC 'offensive behavior' regulation. Sometimes this information is shared with policing agencies like the OPS or RCMP, which has legal ramifications.

When a group of people have an understanding of some place as an anonymous zone, what kind of responsibility do surveillance agents have to that group in respecting the use value the zone has for them? If people use some place as an anonymous zone for activities that cause no demonstrable harm, how can an intervention into that zone for disrupting the activity be justified? Marx (2006) argues that the greatest perceived wrong in collection of personal information is when anonymity is appropriate but not honoured. The 'outing' of men having sex with men in NCC parks then is an abuse in the collection of personal information, since even some NCC and OPS rhetoric (e.g. the idea of a 'pink granite road' and the OPS 'Strategy' document) frames cruising as deserving of anonymity. NCC use of 'beautification' or crime prevention through environmental design to discourage public sex demonstrates how ideas concerning 'appropriate' sex and use of space are embedded in landscaping models. NCC is a development agency, involved in keeping the greenbelt green. On another level, NCC development operates with a specific mandate to cultivate national identity, from which homoeroticism is annulled.

Not all policing agencies seek to eliminate diverse sexualities from the public sphere. Sexual acts between consenting adults have recently been made legal in Amsterdam's Vondel Park. It is significant that public parks are used by heterosexual persons for sex, which differs from the case of bathhouses and tearooms, meaning it is not just homoeroticism but the whole gamut of sexuality that governance agencies like the NCC aim to monitor and expel.

\section{Conclusion: Sex, Space and Surveillance}

Parks are contested spaces. Legislators, land management agencies, and leisure-seekers all have an interest in parks. Surveillance is how what some people do in the park becomes known and regulated as problematic conduct. Authorities must try to blend in as voyeurs so to regulate out sexual activity, which raises interesting questions about space and anonymity, especially as it concerns men having sex with men who seek the anonymity that police-free parks can afford them. Public male with male sexuality is often conflated with child molestation in discourses that frame it is problematic, monstrous, violent, predatory or sick. Though the regulations and the surveillance practices of the NCC are apparently gender-neutral and innocuous, there is a tendency to monitor and intervene in public male with male sexual relation more often. There is thus a bias in the policing of public sex towards elimination of queer sexuality from park locations.

As Flowers and colleagues (1999) argue, men who have sex with men in public parks are less worried about HIV/AIDS and sexually transmitted infections than they are worried about gay bashing, police and community harassment. Likewise, Williams and Robinson (2004) have demonstrated how gays and lesbians feel discriminated against by police. Awareness concerning the importance of safe sex and how to practice safe sex is already high in queer communities. While many men having sex with men learned how to safely engage in sex from the HIV/AIDS health panic of the 1980s and 1990s, heteronormative police and community associations have not learned to accept diverse sexualities. Risk of being ticketed or arrested is of great concern for men having sex with men in parks, since a spoiled reputation with family or co-workers could result. Policing agencies continue to be heteronormative (Myers et al. 2004; Lunny 2003; Namaste 1996) despite recent efforts by police at negotiation with queer communities. 
This paper has demonstrated how NCC officer policing intersects with the normalization of sexuality. Policing of sexuality is also policing the bounds of nationalism. For the National Capital Commission (1965), "the capital of a country...becomes a symbol of nationalism and in miniature represents the spirit and life of its people". If the purpose of the NCC is to promote a vision of Canada and its body politic in Ottawa's parks and greenbelt, this vision is clearly one that does not include homoeroticism or eroticism at all in public, just as Wolfenden would have liked it.

Sexuality and space are not natural, but achieved through contestation. In other words, "heterosexuality is something that is produced (and made to appear natural) through repeated spatial performances and flows of desire... which serve to define what sexual identities and practices are permissible or acceptable in public or private spaces" (Hubbard 2001: 59). Not all gays and lesbians view park sex with the same enthusiasm. Sometimes gays and lesbians who engage in public sex are called out as foes of queer struggles since they disobey Wolfenden's decree that the public and the sexual be mutually exclusive. According to Bell and Binnie (2004: 1815), for "many assimilationist gays...gay male sex zones are seen as an embarrassment that must be cleaned up". This is why Califia (1994) argues public sex is a culture of radical sex, not because its challenges conventional ideas regarding sexuality but because itinerant sex challenges notions of appropriateness regarding space. Policing of eroticism in public parks, then, is not simply a 'gay' or 'straight' issue, and it is not simply a dilemma of urban governance or national identity it is a matter of erotic politics and on what scale we want to conduct our erotic relations with each other.

\section{Acknowledgements}

In addition to the Surveillance \& Society reviewers, thanks to David J. Phillips, Chris Hurl, Justin Piché, Dale Ballucci, Dale Spencer and Kevin Conway for their helpful comments. Thanks to the Surveillance Project people at Queen's University for allowing me to present this paper as part of their ongoing seminar series. Thanks to Mariana Valverde for hosting me at the University of Toronto, Centre of Criminology and providing me an office to work in while I was revising this paper.

\section{References}

Alexander, P. 1996. Bathhouses and Brothels: Symbolic Sites in Discourse and Practice. In Policing Public Sex: Queer Politics and the Future of Aids Activism, ed. Colter, G., W. Hoffman, E. Pendleton, A. Redick, D. Serlin, 221-250. Boston: South End Press.

Aveline, D. 1995. A Typology of Perceived HIV/AIDS Risk-Reduction Strategies Used by Men who "Cruise" other Men for Anonymous Sex. The Journal of Sex Research, 32(3): 201-212.

Bell, D. and J. Binnie. 2004. Authenticating Queer Space: Urbanism and Governance. Urban Studies, 41(9): 1807-1820.

Bell, D. 1995. Perverse Dynamics, Sexual Citizenship and the Transformation of Intimacy. In Mapping Desire: Geographies of Sexualities, ed. Bell, D. and G. Valentine, 304-317. London: Routledge.

Berlant, L. and M. Warner. 1998. Sex in Public. Critical Inquiry, 24(2): 547-566.

Bérubé, A. 1996. The History of Gay Bathhouses. In Policing Public Sex: Queer Politics and the Future of Aids Activism, ed. Colter, G., W. Hoffman, E. Pendleton, A. Redick, D. Serlin, 187-220. Boston: South End Press.

Besmier, M. 2003. Ottawa: Federal Capital and First National Symbol. Queen's Quarterly, 110(2): 196.

Bittner, E. 1967. The Police on Skid-Row: a Study of Peace Keeping. American Sociological Review, 32(5): 699-716.

Blomley, N. 2004. Un-Real Estate: Proprietary Space and Public Gardening. Antipode, 36(4): 614-641.

Califia, P. 1994. Public Sex: The Culture of Radical Sex. San Francisco: Cleis Press.

Carter, T. 2006. Police Use of Discretion: a Participant Observation Study of Game Wardens. Deviant Behavior, 27(4): $591-627$.

Chan, W. and G. Rigakos. 2002. Risk, Crime and Gender. British Journal of Criminology, 42(4): 743-761.

Chauncey, G. 1994. Gay New York: Gender, Urban Culture, and the Making of the Gay Male World, 189-1940. New York: Basic Books.

Conlon, D. 2004. Productive Bodies, Performative Spaces: Everyday Life in Christopher Park. Sexualities, 7(4): $462-479$.

Colter, E., W. Hoffman, E. Pendleton, A. Redick, D. Serlin. 1996. Introduction. In Policing Public Sex: Queer Politics and the Future of Aids Activism, ed. Colter, G., W. Hoffman, E. Pendleton, A. Redick, D. Serlin, 13-20. Boston: South End Press.

Delph, E. 1978. The Silent Community: Public Homosexual Encounters. Beverly Hills: Sage.

Deroches, F. 1990. Tearoom Trade: A Research Update. Qualitative Sociology, 13(1): 39-61.

Edwards, T. 1994. Erotics \& Politics: Gay Male Sexuality, Masculinity and Feminism. London: Routledge.

Ericson, R. 1981. Making Crime: A Study of Detective Work. Toronto: Butterworths.

Foucault, M. 2003. Lives of Infamous Men. In The Essential Foucault. Rabinow, P and N. Rose (eds). London: The New Press. 
Flowers, P., G. Hart, and C. Marriott. 1999. Constructing Sexual Health: Gay Men and "Risk" in the Context of a Public Sex Environment. Journal of Health Psychology, 4(4): 483-495.

Frankis, J. and P. Flowers. 2006. Cruising for Sex: Sexual Risk Behaviors and HIV Testing of Men Who Cruise, Inside and Outwith Public Sex Environment. AIDS Care, 18(1): 54-59.

Hannigan, J. 1998. Fantasy City: Pleasure and Profit in the Postmodern Metropolis. London: Routledge.

Herek, G. 2004. Beyond "Homophobia": Thinking About Sexual Prejudice and Stigma in the Twenty-First Century. Sexuality Research \& Social Policy, 1(2): 6-24.

Hermer, J. 2002. The Nature of Order in North American Parks: Regulating Eden. Toronto: University of Toronto Press.

Hubbard, P. 2001. Sex Zones: Intimacy, Citizenship and Public Space. Sexualities, 4(1): 51-71.

Hubbard, P. 2000. Desire/Disgust: Mapping the Moral Contours of Heterosexuality. Progress in Human Geography, 24(2): 191217.

Huber, J. and P. Kleinplatz. 2002. Sexual Orientation Identification of Men Who Have Sex With Men in Public Settings in Canada. Journal of Homosexuality, 43(2): 1-20.

Humphreys, L. 1975. Tearoom Trade: Impersonal Sex in Public Places. New York: Aldine de Gruyter.

Ip, G. 1987. Woman Objects to Gays Cruising in Park. Ottawa Citizen, June 15: C20.

Johnson, P. 2007. Ordinary Folk and Cottaging: Law, Morality and Public Sex. Journal of Law and Society, 34(4): 520-543.

Kinsman, G. 1996. The Regulation of Desire: Homo and Hetero Sexualities. Black Rose Books: Montreal.

Lee, J. 1979. The Social Organization of Sexual Risk. Alternative Lifestyles, 2: 69-100.

Little, J., R. Panelli, and A. Kraack. 2005. Women's Fear of Crime: A Rural Perspective. Journal of Rural Studies, 21(2): 151163.

Lunny, A. 2003. Provocation and "Homosexual" Advance: Masculinized Subjects as Threat, Masculinized Subjects Under Threat. Social \& Legal Studies, 12(3): 311-333.

Manchulenko, L. 2000. Sex in City Parks Riles West-end Residents: Notorious Spots for Gay Liaisons Target of Police, Public Groups. Ottawa Citizen, March 25: C3.

Marx, G. 2006. What's in a Concept? Some Reflections on the Complications and Complexities of Personal Information and Anonymity. University of Ottawa Law \& Technology Journal, 3(1): 1-34.

Marx, G. 2002. Technology and Gender: Thomas I. Voire and the Case of the Peeping Tom. The Sociological Quarterly, 43(3): 409-433.

Merrick, J. 2002. "Nocturnal Birds" in the Champs-Elysées: Police and Pederasty in Prerevolutionary Paris. The GLQ Archive, 8(3): 425-432.

Myers, K., K. Forest and S. Miller. 2004. Officer Friendly and the Tough Cop: Gays and Lesbians Navigate Homophobia and Policing. Journal of Homosexuality, 47(1): 17-37.

Namaste, K. 1996. Genderbashing: Sexuality, Gender and the Regulation of Public Space. Environment and Planning D: Society and Space, 14(2): 221-240.

National Capital Commission. 1965. An Account of the History, Legislation and Composition of the National Capital Commission together with an Outline of the Work, Projects and Other Functions of the Commission. Ottawa: Information Division of the National Capital Commission.

Oslund, R. 1989. Gays Using Remic Beach Area for Sex Infuriates Residents. Ottawa Citizen, June 22: B1.

Pain, R. 1997. Social Geographies of Women's Fear of Crime. Transactions of the Institute of British Geographers, 22(2): 231244.

Parnaby, P. 2007. Crime Prevention through Environmental Design: Financial Hardship, the Dynamics of Power and the Prospects of Governance. Crime, Law \& Social Change, 48(1): 73-85.

Parnaby, P. 2006. Crime Prevention through Environmental Design: Discourses of Risk, Social Control and a Neo-Liberal Context. Canadian Journal of Criminology, 48(1): 1-29

Pryke, S. 1998. Nationalism and Sexuality, what are the Issues? Nations and Nationalism, 4(4): 529-546.

Ricco, J. 2002. The Logic of the Lure. Chicago: University of Chicago Press.

Rubin, G. 1993. Thinking Sex: Notes for a Radical Theory of the Politics of Sexuality. In The Lesbian and Gay Studies Reader, ed. Abelove, H., M. Barale and D Halperin, 3-44. New York: Routledge.

Schellenberg, K. 1997. Police Information Systems, Information Practices and Individual Privacy. Canadian Public Policy, XXIII(1): 23-39.

Smith, N. 1996. The New Urban Frontier: Gentrification and the Revanchist City. New York: Routledge.

Smith, M. 1991. Those NCC Condoms. Ottawa Citizen, April 15: A10.

Smith, G. 1988. Policing the Gay Community: An Inquiry into Textually-mediated Social Relations. International Journal of the Sociology of Law, 16(2): 163-183.

Tewksbury, R. 1996. Cruising for Sex in Public Places: the Structure and Language of Men's Hidden Erotic Worlds. Deviant Behavior, 17(1): 1-19.

Tewksbury, R. 1995. Adventures in the Erotic Oasis: Sex and Danger in Men's Same-Sex Public Sexual Encounters. Journal of Men's Studies, 4(1): 9-24.

Walby, K. 2009. Surveillance of Male with Male Public Sex in Ontario, 1983-1994. In Surveillance: Power, Problems and Politics, ed. Hier, S. and J. Greenberg, 46-58. Vancouver: UBC Press.

Walby, K. 2006. Locating Televisual and Non-Televisual Textual Sequences with Institutional Ethnography: a Study of Campus and Apartment CCTV Security Work. Culture and Organization, 13(2): 153-168.

Walby, K. 2005. Institutional Ethnography and Surveillance Studies: An Outline for Inquiry. Surveillance and Society, 3(2/3): 158-172. 
Williams, M. and A. Robinson. 2004. Problems and Prospects with Policing the Lesbian, Gay and Bisexual Community in Wales. Policing \& Society, 14(3): 213-232.

Zedner, L. 2007. Pre-Crime and Post-Criminology? Theoretical Criminology, 11(2): 261-281. 